ISSN: 1858-4837; E-ISSN: 2598-019X

Volume 17, Nomor 1 (2022),

https://jurnal.uns.ac.id/region

DOI: $10.20961 /$ region.v17i1.51580

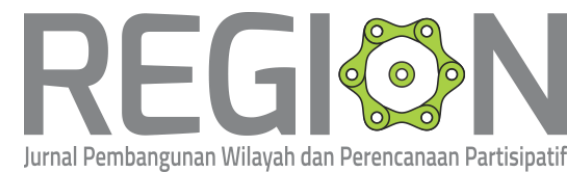

\title{
Tipologi wilayah berdasarkan tingkat kerentanan di wilayah perkotaan Kabupaten Kutai Timur
}

\author{
Regional typology based on vulnerability levels in East Kutai Regency urban \\ areas
}

\author{
A Ghozali ${ }^{1}$ and E Kautsar ${ }^{1}$ \\ ${ }^{1}$ Urban and Regional Planning, Department of Civil Engineering and Planning, Institut \\ Teknologi Kalimantan, Balikpapan, Indonesia
}

Corresponding author's email: ghozali@lecturer.itk.ac.id

\begin{abstract}
Abstrak. Tingkat kejadian bencana kebakaran di wilayah perkotaan Kabupaten Kutai Timur dari tahun 2012 - 2019 mengalami peningkatan jumlah kejadian yang signifikan, terutama pada Kawasan Perkotaan Kabupaten Kutai Timur. Di sisi lain, pemerintah daerah setempat hingga saat ini belum memiliki instrumen pengendalian kejadian kebakaran. Oleh karena itu, penelitian ini bertujuan untuk melakukan pemetaan kerentanan kebakaran di wilayah perkotaan Kabupaten Kutai Timur. Untuk menghasilkan tipologi, analisis overlay pada software ArcGIS digunakan dengan mempertimbangkan faktor fisik, sosial, sarana permukiman, dan kebijakan. Selain itu, pembobotan faktor dengan AHP yang melibatkan tujuh stakeholder kunci digunakan untuk mengetahui faktor prioritas sesuai dengan kondisi kawasan. Hasil analisis diperoleh bahwa kerentanan fisik memiliki bobot 0,45 , kerentanan sosial memiliki bobot 0,33, dan kerentanan ekonomi memiliki bobot 0,22. Dari prioritas faktor ini diperoleh bahwa Kawasan Perkotaan Kutai Timur terdapat tiga tipologi kerentanan kebakaran. Desa Swarga Bara, Desa Singa Gembara, dan Desa Sangatta Selatan memiliki tingkat kerentanan rendah, sedangkan Kelurahan Teluk Lingga memiliki kerentanan sedang, serta Kelurahan Singa Geweh dan Desa Sangatta Utara memiliki tingkat kerentanan tinggi.
\end{abstract}

Kata Kunci: AHP; Kebakaran; Kerentanan

Abstract. The rate of fire disasters in the East Kutai Regency Urban Area from 2012 2019 experienced a significant increase in the number of incidents, especially in the 
East Kutai Regency urban area. On the other hand, the local government does not yet have an instrument for controlling fire incidents. Therefore, this study aims to map the vulnerability of fires in the urban area of the East Kutai Regency. To produce a typology, overlay analysis in ArcGIS software is used by considering physical, social, residential facilities, and policy factors. In addition, factor weighting with AHP involving seven key stakeholders is used to determine priority factors according to the conditions of the area. The results of the analysis show that physical vulnerability weights 0.45 , social vulnerability has a weight of 0.33 , economic vulnerability has a weight of 0.22 . From the priority of these factors, it is found that the East Kutai urban area has three typologies of fire susceptibility. Swarga Bara Village, Singa Gembara Village, and South Sangatta Village have a low level of vulnerability, while Teluk Lingga Village has a moderate vulnerability, and Singa Geweh Village and North Sangatta Village have a high level of vulnerability.

Keywords: AHP; Fire; Vulnerability

\section{Pendahuluan}

Dengan luas wilayah perkotaan sebesar $2.923,44 \mathrm{~km}^{2}$ membuat wilayah perkotaan Kabupaten Kutai Timur mengalami peningkatan kepadatan penduduk dari $40,85 \mathrm{jiwa} / \mathrm{km}^{2}$ pada tahun 2015, menjadi 45,6 jiwa $/ \mathrm{km}^{2}$ pada tahun 2019. Chainey \& Ratcliffe [1] menuliskan bahwa wilayah perkotaan yang berpenduduk padat, berkontribusi terhadap peningkatan kerentanan kebakaran perkotaan. Konsentrasi orang dan bangunan yang tinggi pada suatu permukiman akan menyulitkan operasi pemadaman dan evakuasi saat terjadi kebakaran [2]. Potensi tertinggi bahaya ikutan di Indonesia berada pada wilayah perkotaan yang memiliki kepadatan penduduk tinggi, kompleksitas penggunaan lahan, pemusatan aktivitas penduduk perkotaan, material bangunan, dan adanya daerah-daerah permukiman kumuh perkotaan [3].

Berdasarkan Laporan Bencana 2012-2019 BPBD Kabupaten Kutai Timur, kebakaran dibedakan menjadi dua, yaitu kebakaran permukiman dan kebakaran hutan dan lahan (karhutla). Pada tahun 2012 hingga 2019 telah terjadi 592 kejadian kebakaran. Sebesar 30,24\% diantaranya merupakan kejadian kebakaran permukiman. Pemerintah telah memberikan peningkatan anggaran pada program terkait pencegahan kebakaran pada beberapa perangkat daerah terkait, tetapi tidak efektif karena belum berbasis pada sebaran risiko kebakaran secara keseluruhan. Oleh karena itu, diperlukan adanya upaya lain agar pengurangan dampak bencana kebakaran lebih maksimal. Selain itu, hingga saat ini Dinas Pemadam Kebakaran Kutai Timur hanya menyediakan peta lokasi serta histori lokasi kejadian kebakaran di Kabupaten Kutai Timur.

Mitigasi bencana merupakan kegiatan penting dalam penanggulangan bencana. Kegiatan ini dilakukan sebelum terjadinya bencana sehingga dapat mengurangi dampak akibat bencana baik mengantisipasi korban jiwa serta mengurangi kerugian materil yang dapat ditimbulkan. Pada mitigasi bencana, tindakan antisipatif dilakukan agar dapat mengurangi dampak dari bencana yang terjadi. Adapun tindakan antisipatif tersebut dapat berupa pengaturan tata guna lahan, perencanaan tata ruang, penyusunan data, penyusunan peta kerentanan 
bencana, serta pemantauan dan pengembangan [4]. Untuk mengurangi dampak yang diakibatkan dari kebakaran, maka diperlukan pemetaan zona risiko bencana karena dapat mengantisipasi faktor yang mempengaruhi kejadian kebakaran dan memahami perilaku dinamis penanganan kebakaran [5]. Upaya untuk mengantisipasi dampak dari bencana kebakaran di wilayah perkotaan Kabupaten Kutai Timur salah satunya dapat dilakukan dengan melakukan pemetaan kerentanan bencana kebakaran. Berdasarkan hal tersebut, dalam penanggulangan bencana kebakaran di wilayah perkotaan Kabupaten Kutai Timur diperlukan adanya pemetaan tingkat kerentanan kebakaran berdasarkan pembobotan faktor prioritas.

Penelitian terkait kerentanan kebakaran memang sering dilakukan dengan menggunakan sistem informasi geografis. Meskipun demikian, kerentanan kebakaran permukiman selalu identik dengan kondisi atau kualitas permukiman dan ketersedian fasilitas penanganan kebakaran [2]. Setiap kawasan memiliki karakteristik yang berbeda sehingga dalam penentuan kerentanan perlu memperhatikan faktor yang menjadi kekhasan di kawasan tersebut. Penelitian terdahulu yang dilakukan oleh Somantri [6] dan Anwar [7] yang berfokus pada kondisi fisik permukiman tanpa memperhatikan lebih lanjut faktor prioritas kerentanan. Penelitian lain yang dilakukan oleh Granda dan Ferreira [8] dan Permana, Susanti, dan Wijaya [9] menggunakan sistem informasi geografis dalam melakukan pemetaan kerentanan kebakaran pada sebuah kawasan padat bangunan dengan perhitungan fire risk indeks atau perhitungan dengan harkat yang telah terstandar.

\section{Metode}

\subsection{Lokasi penelitian}

Penelitian ini memiliki ruang lingkup wilayah perkotaan Kabupaten Kutai Timur, Kalimantan Timur yang terdiri dari 2 Kecamatan yaitu Sangatta Utara dan Sangatta Selatan serta 6 kelurahan/desa. Wilayah studi terletak pada $115^{\circ} 56^{\prime} 26^{\prime \prime}$ - $118^{\circ} 58^{\prime} 19^{\prime \prime}$ BT dan 1⒈ $17^{\prime} 1^{\prime \prime}$ LS $1^{\circ} 52^{\prime} 39^{\prime \prime}$ LU serta memiliki luas sebesar $35.747,50 \mathrm{~km}^{2}$. Batas-batas wilayah perkotaan Kabupaten Kutai Timur adalah sebagai berikut:
a. Utara
: Kecamatan Bengalon \& Kecamatan Rantau Pulung
b. Selatan
: Kecamatan Teluk Pandan \& Desa Teluk Sangkima
c. Barat
: Kecamatan Batu Ampar \& Kab. Kutai Kartanegara
d. Timur
: Selat Makassar

\subsection{Teknik pengumpulan data}

Penelitian ini menggunakan metode penelitian kuantitatif. Dalam prosesnya terdapat dua jenis data yaitu data primer dan data sekunder. Data primer dikoleksi dengan menggunakan kuesioner. Kuesioner diberikan dalam rangka penilaian prioritas faktor-faktor kerentanan bencana kebakaran. Penilaian faktor menjadi isu penting dalam penilaian risiko yang secara alami bersifat subjektif [10]. Oleh karena itu, keterlibatan pemangku kepentingan (stakeholder) melalui penilaian yang terstruktur akan meningkatkan hasil penilaian faktor prioritas [11]. Dalam penelitian ini ada 7 (tujuh) stakeholder yang terlibat yaitu Dinas Pemadam Kebakaran, Badan Penanggulangan Bencana Daerah (BPBD), Dinas Perumahan dan 
Permukiman, Badan Perencanaan Pembangunan Daerah (Bappeda) Kabupaten Kutai Timur, Kecamatan Sangatta Utara, Kecamatan Sangatta Selatan, dan akademisi.

Selain itu, data penelitian lain terkait karakteristik fisik, sosial, dan ekonomi kawasan juga dihimpun dari data sekunder yang tersedia di dinas-dinas terkait/ wali data. Data ini digunakan untuk melakukan analisis tipologi kerentanan bencana kebakaran. Beberapa data yang dihimpun dengan survei sekunder ini dapat disajikan pada Tabel 1.

Tabel 1. Data kebutuhan studi dan sumber data.

\begin{tabular}{cll}
\hline No & \multicolumn{1}{c}{ Data } & \multicolumn{1}{c}{ Sumber } \\
\hline 1 & Peta batas administrasi & $\begin{array}{l}\text { Bagian tata pemerintahan dan Bappeda Kabupaten } \\
\text { Kutai Timur }\end{array}$ \\
2 & Peta penggunaan lahan & $\begin{array}{l}\text { Bagian tata pemerintahan dan Bappeda Kabupaten } \\
\text { Kutai Timur } \\
\end{array}$ \\
3 & Jumlah penduduk & Buku Profil Kelurahan dan BPS Kabupaten Kutai Timur \\
4 & Jumlah rumah tangga berpenghasilan rendah & Buku Profil Kelurahan dan BPS Kabupaten Kutai Timur \\
5 & Jumlah penduduk kelompok umur rentan & Buku Profil Kelurahan dan BPS Kabupaten Kutai Timur \\
6 & Jumlah orang cacat/disabilitas & Buku Profil Kelurahan dan BPS Kabupaten Kutai Timur \\
7 & Sebaran hidran & Dinas Pemadam Kebakaran Kabupaten Kutai Timur \\
8 & Jenis bangunan & Observasi wilayah studi \\
9 & Kepadatan bangunan & Interpretasi citra satelit Google \\
10 & Lebar jalan & Observasi wilayah studi dan interpretasi citra satelit \\
& & Google \\
\hline
\end{tabular}

\subsection{Metode analisis data}

2.3.1. Analisis faktor prioritas kerentanan kebakaran wilayah perkotaan Kabupaten Kutai Timur. Metode yang digunakan untuk menentukan faktor prioritas kerentanan kebakaran permukiman adalah analisis AHP (Analytical Hierarchy Process) dengan software super decisions. AHP bertujuan untuk menghasilkan nilai bobot masing-masing faktor melalui struktur penilaian berjenjang dan perbandingan pairwise sehingga ukuran seberapa penting faktor yang menjadi pertimbangan dalam penentuan risiko dapat dianalisis secara efisien [12]. Dalam analisis ini responden akan memberikan penilaian perbandingan antara faktor satu dengan faktor lainnya berdasarkan skala angka dari yang tidak penting hingga sangat penting. Dengan AHP, pengetahuan para ahli dapat dirangkum dalam sebuah ukuran bobot kategori dan faktor dari setiap penilaian individu [13]. Bobot yang merepresentasikan tingkat prioritas atau kepentingan faktor terhadap faktor lain berguna sebagai input untuk perhitungan tingkat kerentanan bencana kebakaran di wilayah perkotaan Kabupaten Kutai Timur nantinya. Dalam prosesnya analisis ini dilakukan dengan beberapa tahapan:

a. Mendefinisikan hierarki faktor. Faktor diperoleh dari studi literatur yang berkaitan dengan manajemen risiko bencana kebakaran. Dari studi literatur didapatkan 3 kategori dan 10 faktor yang dapat dipertimbangkan dalam penentuan tingkat kerentanan seperti pada Tabel 2. Hierarki didefinisikan sebagai turunan kategori digambarkan secara horizontal sejumlah kategori dan jumlah faktor dalam setiap kategori. 
Tabel 2. Variabel penelitian.

\begin{tabular}{|c|c|c|}
\hline Kategori & Faktor & Definisi Operasional \\
\hline \multirow[t]{4}{*}{ Fisik } & $\begin{array}{l}\text { (a) Persentase jenis bangunan } \\
\text { (permanen) }\end{array}$ & $\begin{array}{l}\text { Jumlah jenis bahan bangunan permanen / total } \\
\text { bangunan per kelurahan (\%) }\end{array}$ \\
\hline & (b) Kepadatan bangunan netto & $\begin{array}{l}\text { Persentase perbandingan jumlah total luas } \\
\text { bangunan dibandingkan dengan luas wilayah } \\
\text { permukiman per kelurahan (\%) }\end{array}$ \\
\hline & (c) Lebar jalan & $\begin{array}{l}\text { Ukuran rata - rata lebar jalan masuk lingkungan } \\
\text { permukiman pada Kelurahan di wilayah perkotaan } \\
\text { Kabupaten Kutai Timur (m) }\end{array}$ \\
\hline & (d) Ketersediaan hidran & Lokasi hidran umum di setiap kelurahan \\
\hline \multirow[t]{4}{*}{ Sosial } & $\begin{array}{l}\text { (a) Persentase penduduk kelompok } \\
\text { umur 0-5 tahun dan } 65 \text { tahun keatas }\end{array}$ & $\begin{array}{l}\text { Persentase penduduk kelompok umur 0-5 tahun } \\
\text { dan } 65 \text { tahun keatas per kelurahan (\%) }\end{array}$ \\
\hline & (b) Kepadatan penduduk netto & $\begin{array}{l}\text { Perbandingan jumlah bangunan dengan luas } \\
\text { wilayah permukiman (jiwa/ } / \mathrm{km}^{2} \text { ) }\end{array}$ \\
\hline & (c) Persentase orang cacat & $\begin{array}{l}\text { Persentase penduduk penyandang cacat (cacat } \\
\text { tuna rungu, tuna netra, tuna daksa, ataupun cacat } \\
\text { mental) terhadap jumlah penduduk seluruhnya di } \\
\text { setiap kelurahan (\%) }\end{array}$ \\
\hline & (d) Presentasi jenis kelamin & $\begin{array}{l}\text { Persentase jenis kelamin perempuan } \\
\text { dibandingkan dengan jumlah penduduk pada } \\
\text { kelurahan (\%) }\end{array}$ \\
\hline \multirow[t]{2}{*}{ Ekonomi } & (a) Persentase rumah tangga miskin & $\begin{array}{l}\text { Persentase jumlah rumah tangga berpenghasilan } \\
\text { rendah terhadap jumlah rumah tangga seluruhnya } \\
\text { di setiap kelurahan (\%) }\end{array}$ \\
\hline & $\begin{array}{l}\text { (b) Persentase rumah tangga bekerja } \\
\text { di sektor berlokasi rentan }\end{array}$ & $\begin{array}{l}\text { Persentase rumah tangga yang bekerja di daerah } \\
\text { yang rentan akan kebakaran seperti pegawai toko, } \\
\text { pedagang kaki lima, dan pegawai kantoran (\%) }\end{array}$ \\
\hline
\end{tabular}

b. Penilaian stakeholder. Penilaian yang dimaksudkan adalah untuk membandingkan nilai tiap faktor satu per satu secara berpasangan. Adapun penilaian ini dilakukan oleh seluruh responden terpilih dengan skala penilaian 1 (jika kedua faktor yang dibandingkan memiliki tingkat kepentingan yang sama) sampai dengan 9 (jika satu faktor mutlak lebih penting dari faktor lain) [14]. Hasil penilaian pada masing-masing preferensi responden yang ada di dalam kuesioner kemudian dihitung rata-rata penilaiannya (geometric mean) yang kemudian dimasukkan ke dalam matriks berpasangan pada software super decisions.

c. Perhitungan bobot faktor dan penarikan kesimpulan. Setelah selesai memasukkan nilai geometric mean pada matriks perbandingan berpasangan, selanjutnya dilakukan penarikan kesimpulan tingkat prioritas dan nilai bobot masing-masing faktor. Hasil perhitungan dapat diterima atau valid jika nilai rasio konsistensi $(C R) \leq 0,1$ [15]. Apabila nilai konsistensi $C R>$ 0.1 , maka dikatakan tidak valid atau tidak konsisten sehingga responden harus mengulangi pengisian pada kuesioner penilaian. 
2.3.2. Analisis tipologi wilayah berdasarkan tingkat kerentanan kebakaran di wilayah perkotaan Kabupaten Kutai Timur. Dalam menyelesaikan analisis ini dilakukan dengan analisis spasial/GIS dengan bantuan aplikasi ArcGIS 10.6. Metode yang digunakan adalah weighted sum overlay. Tipologi wilayah yang dihasilkan didasarkan dari bobot faktor yang telah didapatkan pada analisis sebelumnya. Beberapa tahapan analisis yang dilakukan antara lain:

a. Reclassify faktor kerentanan. Setelah mengetahui kondisi eksisting pada tiap faktor, selanjutnya dilakukan proses klasifikasi untuk menyamakan nilai pada tiap faktor. Pada proses klasifikasi, data dikelaskan ulang harus dalam bentuk raster. Pengkelasan pada masing-masing faktor menggunakan tools reclassify sesuai dengan Peraturan Kepala BNPB Nomor 02 Tahun 2012 tentang Pedoman Umum Pengkajian Risiko Bencana [16] yang mengeluarkan panduan untuk nilai dari masing-masing variabel kerentanan dan dikombinasikan dengan penelitian $[2,17]$. Kelas yang dipakai pada penelitian ini terdiri dari kelas rendah, sedang, dan tinggi. Dimana memiliki bobot nilai sendiri secara berurutan yaitu 1, 2, dan 3 . Tabel 3 menunjukkan parameter kelas faktor yang digunakan.

Tabel 3. Kelas faktor kerentanan kebakaran.

\begin{tabular}{|c|c|c|c|c|}
\hline \multirow{2}{*}{ Faktor } & \multicolumn{3}{|c|}{ Kelas (Skor) } & \multirow{2}{*}{ Sumber } \\
\hline & Rendah (1) & Sedang (2) & Tinggi (3) & \\
\hline $\begin{array}{l}\text { - Jenis bangunan } \\
\text { (permanen) }\end{array}$ & $>75 \%$ & $40 \%-75 \%$ & $<40 \%$ & [2] \\
\hline $\begin{array}{l}\text { - Kepadatan } \\
\text { bangunan netto }\end{array}$ & $5 \%-20 \%$ & $20 \%-60 \%$ & $20 \%-60 \%$ & [17] \\
\hline - Lebar jalan & Lebar 6 m & Lebar 3-6 m & Lebar <3 m & [17] \\
\hline - Ketersediaan hidran & $\begin{array}{c}>75 \% \text { Berjarak } \\
\text { kurang dari } \\
500 \mathrm{~m}\end{array}$ & $\begin{array}{l}\text { 40\%-75\% Berjarak kurang dari } \\
500 \mathrm{~m} \text { dan } \\
>75 \% \text { Berjarak antara } 500 \mathrm{~m}- \\
1.000 \mathrm{~m}\end{array}$ & $\begin{array}{c}<75 \% \text { Berjarak } \\
\text { antara } 500 \mathrm{~m}- \\
1.000 \mathrm{~m}\end{array}$ & [2] \\
\hline $\begin{array}{l}\text { - Persentase } \\
\text { penduduk kelompok } \\
\text { umur 0-5 tahun dan } \\
65 \text { tahun keatas } \\
\text { (rentan) }\end{array}$ & $<20 \%$ & $20 \%-40 \%$ & $>40 \%$ & [16] \\
\hline $\begin{array}{l}\text { - Presentasi jenis } \\
\text { kelamin }\end{array}$ & $<20 \%$ & $20 \%-40 \%$ & $>40 \%$ & [16] \\
\hline $\begin{array}{l}\text { - Kepadatan } \\
\text { penduduk netto }\end{array}$ & $<5 \mathrm{jiwa} / \mathrm{ha}$ & 5-10 jiwa/ha & $>10$ jiwa/ha & [16] \\
\hline $\begin{array}{l}\text { - Persentase orang } \\
\text { cacat }\end{array}$ & $<20 \%$ & $20 \%-40 \%$ & $>40 \%$ & [16] \\
\hline $\begin{array}{l}\text { Persentase rumah } \\
\text { tangga miskin }\end{array}$ & $<20 \%$ & $20 \%-40 \%$ & $>40 \%$ & [16] \\
\hline $\begin{array}{l}\text { - Persentase rumah } \\
\text { tangga yang bekerja } \\
\text { di sektor rentan }\end{array}$ & $<20 \%$ & $20 \%-40 \%$ & $>40 \%$ & [16] \\
\hline
\end{tabular}


b. Overlay faktor per kategori kerentanan. Pada tahap ini dilakukan overlay untuk faktor pada setiap kategori. Dengan demikian pada prosesnya akan dihasilkan 3 (tiga) kategori peta kerentanan sesuai dengan kelompok faktor. Contoh untuk menghasilkan peta kerentanan fisik yang merupakan hasil overlay dari peta persentase jenis bangunan (permanen), peta kepadatan bangunan netto, peta lebar jalan, dan peta ketersediaan hidran. Tahapan ini menggunakan tools overlay weighted sum dengan bobot yang diberikan sesuai dengan hasil yang didapatkan pada analisis sebelumnya. Berikut ilustrasi overlay pada masingmasing kerentanan kekeringan pada penelitian ini (lihat Gambar 1).

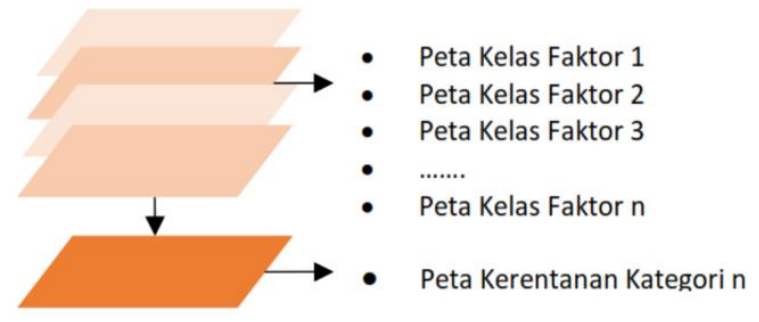

(a)

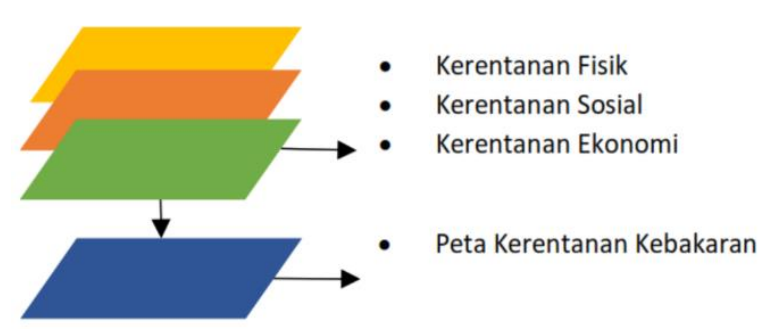

(b)

Gambar 1. Ilustrasi overlay (a) per faktor dalam satu kategori dan (b) antar kategori.

c. Overlay tipologi dari 3 komponen kerentanan. Dari tahapan analisis sebelumnya didapatkan peta kerentanan fisik, peta kerentanan sosial, dan peta kerentanan ekonomi. Selanjutnya adalah melakukan proses overlay yang sama pada ketiga peta tersebut dengan bobot yang diberikan sehingga dihasilkan peta tingkat kerentanan kebakaran total. Berikut ilustrasi analisis overlay weighted sum.

d. Reclassify peta tingkat kerentanan kebakaran. Hasil analisis overlay weighted sum yang telah didapatkan dari peta kerentanan fisik, sosial, dan ekonomi menghasilkan nilai kerentanan total yang terdapat di wilayah perkotaan Kabupaten Kutai Timur. Untuk mempermudah interpretasi hasil dilakukan klasifikasi kelas dengan Teknik proporsi nilai dari total nilai hasil analisis overlay. Pada penelitian ini, tingkat kerentanan kebakaran dibagi ke dalam 3 kelas yaitu kelas rendah, kelas sedang, dan kelas tinggi. Proses proporsi interval kelas menggunakan persamaan sebagai berikut.

Keterangan:

$$
I K=\frac{\text { Nilai tertinggi-Nilai Terendah }}{\text { Jumlah Kelas }}(3)
$$

IK adalah Interval Kelas

\section{Hasil penelitian dan pembahasan}

\subsection{Gambaran kondisi wilayah studi}

3.1.1. Kondisi bangunan dan lahan terbangun. Sebagai wilayah perkotaan dan ibukota Kabupaten Kutai Timur. Wilayah studi memiliki jumlah bangunan pada tiap kelurahan/desa. Desa Sangatta Utara memiliki jumlah bangunan terbanyak di wilayah perkotaan Kabupaten Kutai Timur dengan jumlah sebanyak 22843 unit, adapun Desa Sangatta Selatan merupakan 
desa dengan jumlah bangunan paling sedikit dengan jumlah 2103 unit. Dengan jumlah total bangunan 49402 unit, sebagian besar bahan bangunan menggunakan bahan kayu sebagai bahan utamanya dan hanya sebagian menggunakan perkerasan semen atau bangunan permanen. Luas lahan terbangun memiliki kondisi yang sama atau berbanding lurus dengan jumlah bangunan. Desa Sangatta Utara memiliki total luas bangunan terbesar wilayah perkotaan Kabupaten Kutai Timur dengan total luas $5,2 \mathrm{~km}^{2}$, hal ini berbanding lurus dengan jumlah total bangunan yang ada di Desa Sangatta Utara. Sedangkan Kelurahan Singa Geweh memiliki total luas bangunan terkecil yaitu sebesar $0,6 \mathrm{~km}^{2}$. Tabel 4 menunjukkan kondisi keseluruhan bangunan di wilayah studi.

Tabel 4. Kondisi bangunan dan lahan terbangun per kelurahan.

\begin{tabular}{lccc}
\hline Kelurahan/Desa & $\begin{array}{c}\text { Total Jumlah } \\
\text { Bangunan (unit) }\end{array}$ & $\begin{array}{c}\text { Jumlah Jenis } \\
\text { Bangunan Permanen }\end{array}$ & $\begin{array}{c}\text { Total Luas } \\
\text { Bangunan } \mathbf{( k m}^{\mathbf{2}} \text { ) }\end{array}$ \\
\hline Desa Sangatta Selatan & 2103 & 231 & 1,2 \\
Desa Sangatta Utara & 22843 & 3139 & 5,2 \\
Desa Singa Gembara & 7802 & 1,528 & 2,8 \\
Desa Swarga Bara & 5941 & 2454 & 2,8 \\
Kelurahan Singa Geweh & 2383 & 217 & 0,6 \\
Kelurahan Teluk Lingga & 8331 & 1381 & 3,3 \\
\hline
\end{tabular}

3.1.2. Kondisi sarana dan prasarana. Saat ini jalan di wilayah perkotaan Kabupaten Kutai Timur sudah merata dan tidak hanya memusat di permukiman. Berdasarkan fungsinya, di wilayah studi terdapat 1 ruas jalan arteri, 9 ruas jalan kolektor, dan 4 ruas jalan lokal. Selain itu, pada wilayah perkotaan Kabupaten Kutai Timur banyak jalan lingkungan yang memiliki lebar variatif. Rata-rata lebar jalan lingkungan pada tiap kelurahan/desa di wilayah perkotaan Kabupaten Kutai Timur memiliki lebar antara 3,7 m hingga 5,9 m (lihat Tabel 5). Rata - rata lebar jalan terbesar ada di Desa Swarga Bara. Ketersediaan jalan yang lebar memudahkan penanganan kebakaran. Namun, pada kondisi eksistingnya di wilayah perkotaan Kabupaten Kutai Timur tidak ditemukannya adanya hidran.

Tabel 5. Kondisi lebar jalan per kelurahan.

\begin{tabular}{lc}
\hline \multicolumn{1}{c}{ Kelurahan/Desa } & Rata - Rata Lebar Jalan Masuk (m) \\
\hline Desa Sangatta Selatan & 3,8 \\
Desa Sangatta Utara & 4,0 \\
Desa Singa Gembara & 4,5 \\
Desa Swarga Bara & 5,9 \\
Kelurahan Singa Geweh & 3,7 \\
Kelurahan Teluk Lingga & 3,9 \\
\hline
\end{tabular}

3.1.3. Kondisi sosial. Jumlah penduduk wilayah perkotaan Kabupaten Kutai Timur memiliki jumlah yang berbeda-beda pada tiap kelurahan/desanya. jumlah penduduk terbanyak terdapat pada Desa Sangatta Selatan dengan jumlah 66174 jiwa, sedangkan Kelurahan Singa Geweh memiliki jumlah penduduk dengan jumlah paling sedikit dengan jumlah 6958 jiwa. Kejadian kebakaran sangat dirasakan oleh kelompok penduduk rentan sehingga dalam penanganannya kelompok ini perlu diprioritaskan. Kelompok umur rentan adalah penduduk 
dengan rentang umur $0-5$ tahun dan 60 tahun ke atas. Wilayah perkotaan Kabupaten Kutai Timur, Desa Sangatta Utara memiliki jumlah penduduk kelompok umur rentan terbanyak dengan jumlah 8346 jiwa, sedangkan Kelurahan Singa Geweh memiliki jumlah kelompok umur terendah yaitu sebanyak 855 jiwa. Selain kelompok umur rentan juga terdapat kelompok disabilitas yang juga perlu diperhatikan. Desa Swarga Bara memiliki jumlah orang cacat terendah di wilayah studi dengan jumlah 70 jiwa, sementara Desa Sangatta Utara memiliki jumlah orang cacat terbesar dengan jumlah 443 jiwa. Secara lengkap, kondisi sosial wilayah perkotaan Kabupaten Kutai Timur dapat ditinjau pada Tabel 6.

Tabel 6. Kondisi sosial per kelurahan.

\begin{tabular}{lcccc}
\hline Kelurahan/Desa & $\begin{array}{c}\text { Jumlah } \\
\text { Penduduk (Jiwa) }\end{array}$ & $\begin{array}{c}\text { Jumlah Kelompok } \\
\text { Umur Rentan } \\
\text { (Jiwa) }\end{array}$ & $\begin{array}{c}\text { Jumlah Orang } \\
\text { Cacat (Jiwa) }\end{array}$ & $\begin{array}{c}\text { Jumlah Jenis } \\
\text { Kelamin } \\
\text { Perempuan (Jiwa) }\end{array}$ \\
\hline Desa Sangatta Selatan & 7099 & 931 & 104 & 3941 \\
Desa Sangatta Utara & 66174 & 8436 & 443 & 29192 \\
Desa Singa Gembara & 20497 & 2570 & 166 & 9078 \\
Desa Swarga Bara & 16555 & 2192 & 70 & 7651 \\
Kelurahan Singa Geweh & 6958 & 855 & 83 & 3294 \\
Kelurahan Teluk Lingga & 23922 & 3764 & 172 & 12014 \\
\hline
\end{tabular}

3.1.4. Kondisi ekonomi. Tabel 7 di bawah ini menunjukkan bahwa jumlah rumah tangga miskin di wilayah perkotaan Kabupaten Kutai Timur paling banyak terdapat di Desa Sangatta Utara dengan jumlah 1447 jiwa, sedangkan paling sedikit terdapat pada Desa Swarga Bara dengan jumlah 283 jiwa. Selain itu, jumlah rumah tangga sektor rentan pada tiap kelurahan/desa di wilayah perkotaan Kabupaten Kutai Timur memiliki jumlah yang berbeda-beda. Rumah tangga sektor rentan adalah yang beraktifitas pada pemanfaatan bangunan.

Tabel 7. Kondisi ekonomi per kelurahan.

\begin{tabular}{lcc}
\hline Kelurahan/Desa & Jumlah Rumah Tangga Miskin & $\begin{array}{c}\text { Jumlah Rumah Tangga Bekerja di } \\
\text { sektor rentan (Jiwa) }\end{array}$ \\
\hline Desa Sangatta Selatan & 340 & 176 \\
Desa Sangatta Utara & 1447 & 1472 \\
Desa Singa Gembara & 644 & 420 \\
Desa Swarga Bara & 283 & 219 \\
Kelurahan Singa Geweh & 274 & 194 \\
Kelurahan Teluk Lingga & 595 & 752 \\
\hline
\end{tabular}

\subsection{Hasil analisis faktor prioritas}

Hierarki faktor dibentuk dari kategori (cluster) dan faktor (node) yang dihubungkan. Kemudian, penilaian perbandingan secara berpasangan pada hal yang bersifat homogen, yaitu antar faktor dan antar kategori dilakukan oleh 7 (tujuh) responden sesuai dengan bidang ahlinya masing-masing.

Hasil perbandingan antar faktor dalam satu kategori dapat disajikan pada Tabel 8. Pada kategori fisik terlihat bahwa faktor kondisi bangunan 2,29 kali lebih penting daripada faktor lebar jalan menurut agregasi perbandingan berpasangan seluruh stakeholder. Nilai ini menjadi 
perbandingan terbesar pada kategori fisik. Dalam menjawab perbandingan kategori fisik, seluruh stakeholder konsisten yang terlihat dari nilai inconsistency sebesar $19 \times 10^{-15}$.

Tabel 8. Perbandingan pairwise agregat stakeholder pada setiap kategori.

\begin{tabular}{|c|c|c|c|c|}
\hline \multicolumn{5}{|c|}{ Perbandingan Pairwise Pada Kategori Faktor Sosial } \\
\hline Faktor Fisik & $\begin{array}{l}\text { Ketersediaan } \\
\text { hidran }\end{array}$ & $\begin{array}{c}\text { Kepadatan } \\
\text { bangunan }\end{array}$ & $\begin{array}{c}\text { Kondisi } \\
\text { bangunan }\end{array}$ & Lebar jalan \\
\hline Ketersediaan hidran & 1,00 & 1,27 & 0,71 & 1,63 \\
\hline Kepadatan bangunan & 0,79 & 1,00 & 0,56 & 1,29 \\
\hline Kondisi bangunan & 1,40 & 1,78 & 1,00 & 2,29 \\
\hline Lebar jalan & 0,61 & 0,78 & 0,44 & 1,00 \\
\hline \multicolumn{5}{|c|}{ Perbandingan Pairwise Kategori Faktor Sosial } \\
\hline Faktor Sosial & $\begin{array}{c}\text { Kepadatan } \\
\text { penduduk }\end{array}$ & $\begin{array}{c}\text { Penduduk } \\
\text { umur rentan }\end{array}$ & $\begin{array}{c}\text { Persentase jenis } \\
\text { kelamin }\end{array}$ & $\begin{array}{l}\text { Persentase } \\
\text { orang cacat }\end{array}$ \\
\hline Kepadatan penduduk & 1,00 & 2,23 & 3,33 & 2,49 \\
\hline Penduduk umur rentan & 0,45 & 1,00 & 1,49 & 1,11 \\
\hline Persentase jenis kelamin & 0,30 & 0,67 & 1,00 & 0,75 \\
\hline Persentase orang cacat & 0,40 & 0,90 & 1,34 & 1,00 \\
\hline \multicolumn{5}{|c|}{ Perbandingan Pairwise Kategori Faktor Ekonomi } \\
\hline Faktor Ekonomi & $\begin{array}{c}\text { Persentase } \\
\text { rumah tangga } \\
\text { miskin }\end{array}$ & $\begin{array}{c}\text { Persentase } \\
\text { rumah tangga } \\
\text { sektor rentan }\end{array}$ & & \\
\hline $\begin{array}{l}\text { Persentase rumah tangga } \\
\text { miskin }\end{array}$ & 1,00 & 0,81 & & \\
\hline $\begin{array}{l}\text { Persentase rumah tangga } \\
\text { sektor rentan }\end{array}$ & 1,23 & 1,00 & & \\
\hline
\end{tabular}

Tabel 9. Bobot faktor dan kategori prioritas kerentanan kebakaran.

\begin{tabular}{llll}
\hline Aspek & Bobot & \multicolumn{1}{c}{ Kriteria } & Bobot \\
\hline Kerentanan fisik & 0,45 & Hidran & 0,26 \\
& & Kepadatan bangunan & 0,21 \\
& & Kondisi bangunan & 0,37 \\
& & Lebar jalan & 0,16 \\
\hline Kerentanan sosial & \multirow{2}{*}{0,33} & Kepadatan penduduk & 0,47 \\
& & Penduduk umur rentan & 0,21 \\
& & Persentase jenis kelamin & 0,14 \\
\cline { 3 - 4 } & & Persentase orang cacat & 0,19 \\
\hline Kerentanan ekonomi & 0,22 & Persentase rumah tangga miskin & 0,45 \\
& & Persentase rumah tangga sektor rentan & 0,56 \\
\hline
\end{tabular}

Pada kategori sosial juga diketahui bahwa persentase kepadatan penduduk menjadi faktor yang sangat diperhatikan oleh para stakeholder. Hal ini terlihat dari nilai perbandingan berpasangan terhadap faktor lain selalu di atas 2 . Selain itu, pada perbandingan kategori ekonomi, persentase rumah tangga sektor rentan menjadi faktor kunci yang menjadi 
perhatian responden. Tidak jauh berbeda pada kategori fisik, nilai inkonsistensi agregat dari seluruh stakeholder pada kategori sosial dan ekonomi sangat kecil yaitu berturut-turut sebesar $3 \times 10^{-14}$ dan $4 \times 10^{-16}$.

Setelah itu dari matriks perbandingan yang dihasilkan, disimpulkan nilai bobot dan tingkat prioritas masing-masing faktor dan kategori. Melalui judgment pada software super decision didapatkan nilai perbandingan akhir seperti pada Tabel 9. Nilai ini sebagai bobot faktor (weight) yang digunakan dalam analisis overlay data untuk menghasilkan tipologi.

\subsection{Hasil analisis tipologi kerentanan kebakaran}

3.3.1. Tingkat kerentanan pada kategori fisik. Berdasarkan data kondisi fisik, sosial, dan ekonomi yang telah diuraikan pada bagian sebelumnya, data kemudian diklasifikasikan berdasarkan parameter pada Tabel 9 dan ditampilkan pada Gambar 2. Seluruh wilayah perkotaan ini tidak memiliki hidran sehingga memiliki tingkat kerentanan yang tinggi. Berbanding terbalik dengan kondisi hidran, pada faktor kepadatan bangunan justru masih termasuk dalam tingkat rendah meskipun di beberapa kelurahan memiliki jumlah bangunan yang banyak. Selain itu, dengan lebar jalan lingkungan antara 3-5 meter, maka seluruh wilayah berisiko sedang. Tingkatan yang sedikit beragam terjadi pada faktor kondisi bangunan dimana hanya Desa Swarga Bara memiliki kerentanan sedang. Hal ini karena masih banyak bangunan non permanen.

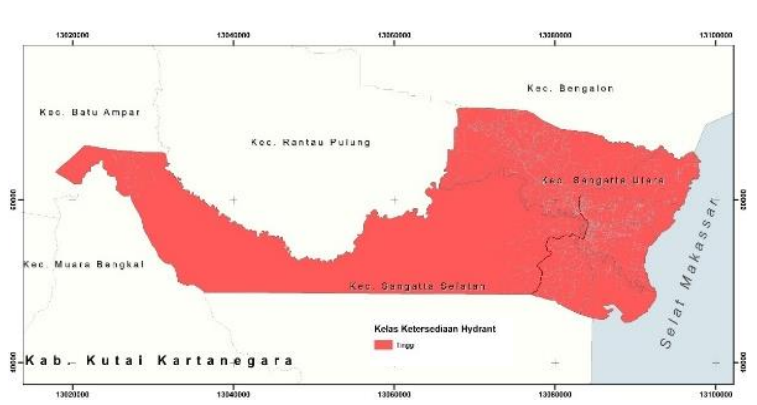

(a)

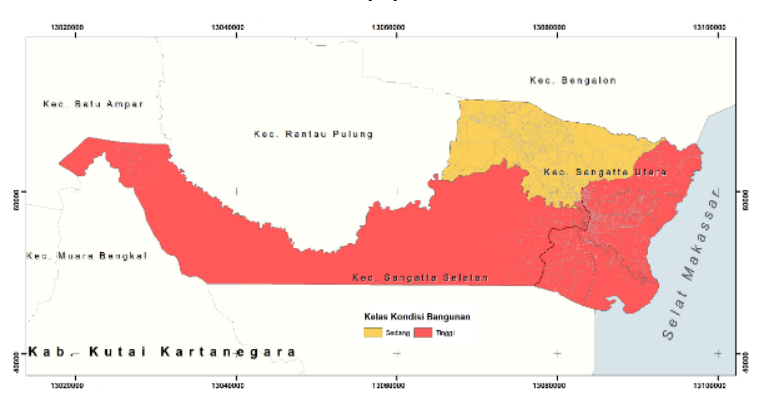

(c)

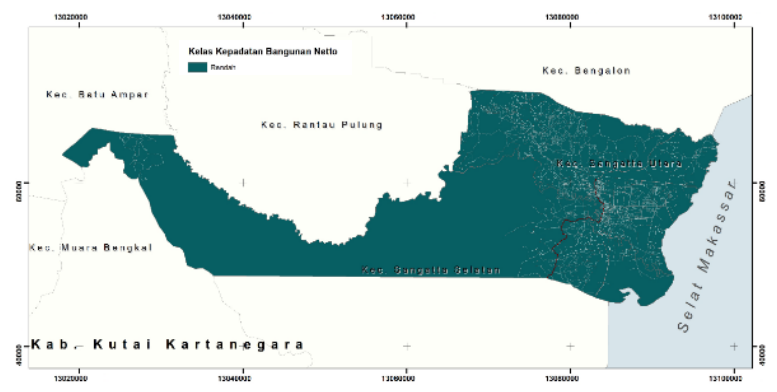

(b)

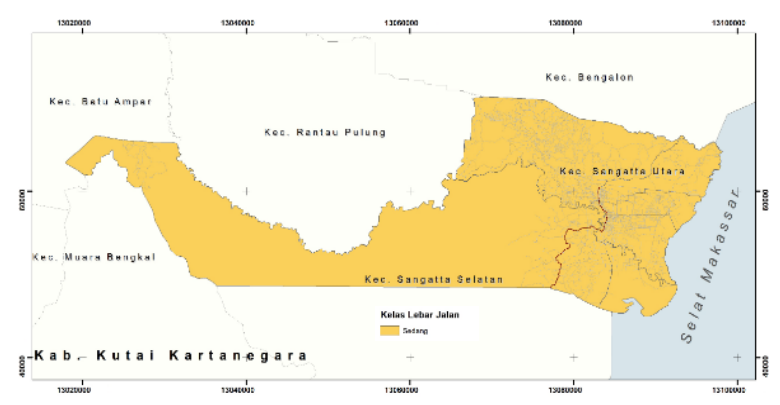

(d)

Gambar 2. Peta tingkat kerentanan fisik berdasarkan (a) ketersediaan hidran, (b) kepadatan bangunan netto, (c) kondisi bangunan, dan (d) lebar jalan. 
Setelah data pada setiap faktor dikelaskan maka selanjutnya dilakukan proses weighted sum overlay dengan bobot sesuai dengan hasil analisis AHP. Hasil analisis ini disajikan pada Gambar 3. Berdasarkan peta tersebut dapat diketahui bahwa pada Desa Swarga Bara memiliki tingkat kerentanan terkecil pada aspek fisik yaitu sebesar 0,93, sedangkan kelurahan/desa lainnya memiliki tingkat kerentanan sebesar 1.1.

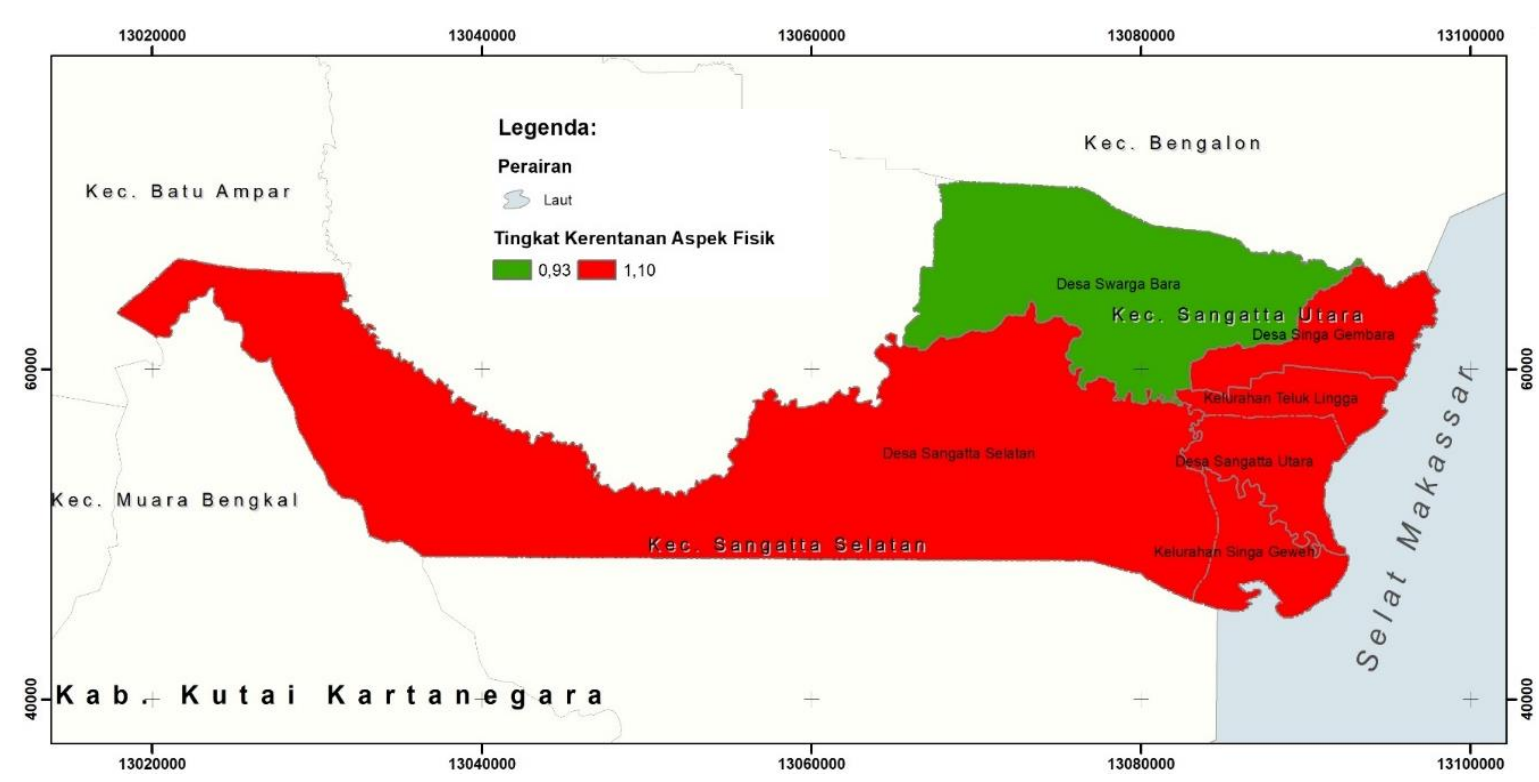

Gambar 3. Peta hasil overlay kerentanan kategori fisik.

Pada kategori fisik ini sangat dipengaruhi oleh kondisi bangunan karena hamper seluruh faktor di setiap kelurahan sama, maka yang membedakan hanyalah faktor kondisi bangunan. Desa Swarga Bara yang memiliki tingkat bangunan permanen lebih besar memiliki kerentanan yang lebih rendah dari kelurahan lain.

3.3.2. Tingkat kerentanan pada kategori sosial. Pada kategori sosial, seluruh wilayah memiliki tingkat kerentanan yang sama pada faktor kelompok umur rentan, penduduk cacat, dan persentase jenis kelamin. Meskipun secara jumlah ketiga faktor tersebut beragam tetapi persentase pada setiap kelurahan/desa memiliki nilai yang tidak jauh berbeda. Seperti pada Gambar 3, kondisi berbeda justru terjadi pada klasifikasi faktor kepadatan penduduk bersih (berbanding dengan kawasan terbangun) yang beragam. Kelurahan Sangatta Utara memiliki tingkat kerentanan tinggi karena menjadi konsentrasi penduduk tertinggi di wilayah ini. Sebaliknya, Kelurahan Sangatta Selatan dan Sungai Geweh memiliki kerentanan rendah dengan penduduk di bawah 10 ribu jiwa atau dengan kepadatan $<5$ jiwa/ha. Hasil analisis weighted sum overlay pada kategori sosial dapat disajikan pada Gambar 4. Karena hampir seluruh kelurahan/desa memiliki kesamaan kondisi pada hampir seluruh faktor, maka kerentanan sosial hanya dibedakan dari faktor kepadatan penduduk. Dari peta tersebut dapat diketahui, bahwa Desa Sangatta Selatan, Desa Swarga Bara, dan Kelurahan Teluk Lingga memiliki tingkat kerentanan pada aspek sosial sebesar 0,43. Sedangkan Desa Sangatta Utara, 
Desa Singa Gembara, dan Kelurahan Singa Geweh memiliki tingkat kerentanan pada aspek sosial yang lebih besar yaitu sebesar 0,88. Hasil analisis ini disajikan pada Gambar 5.

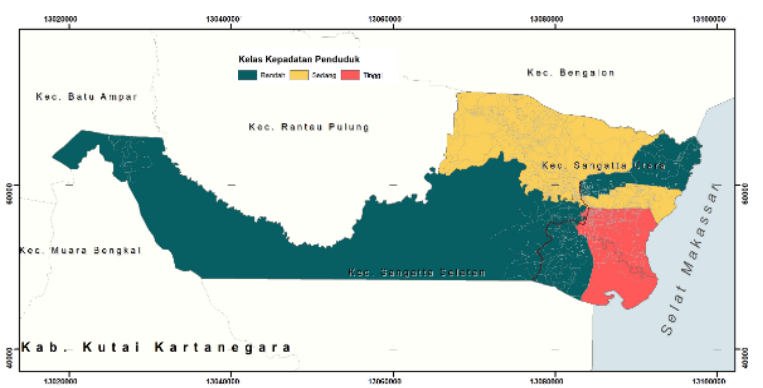

(a)

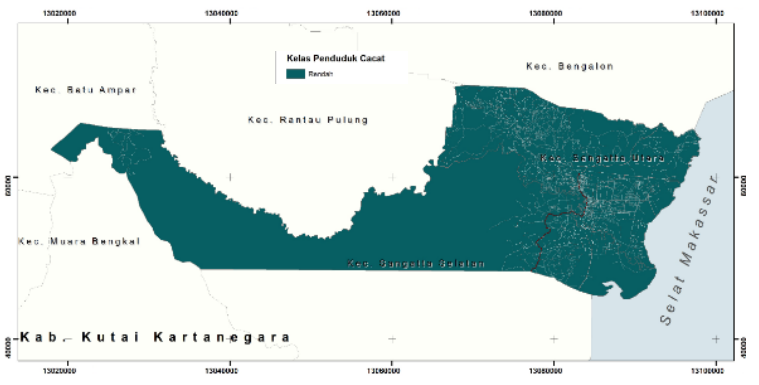

(c)

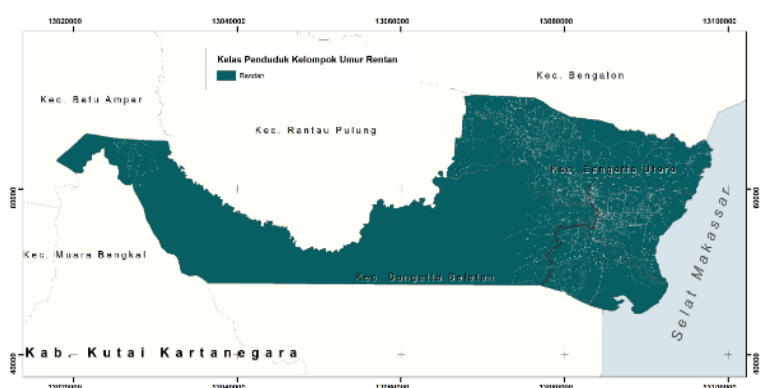

(b)

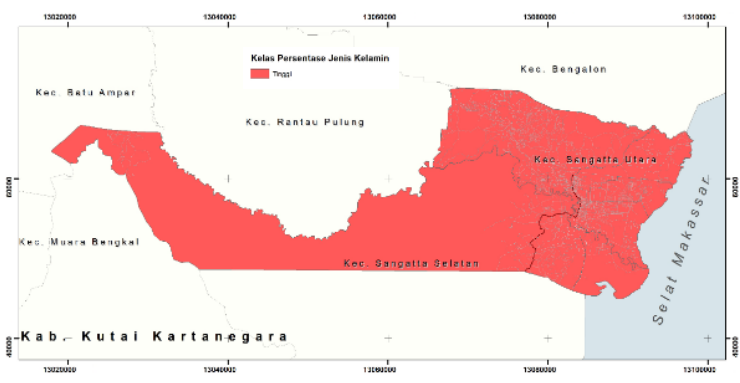

(d)

Gambar 4. Peta tingkat kerentanan sosial berdasarkan (a) kepadatan penduduk, (b) kelompok umur rentan, (c) penduduk cacat, dan (d) persentase jenis kelamin.

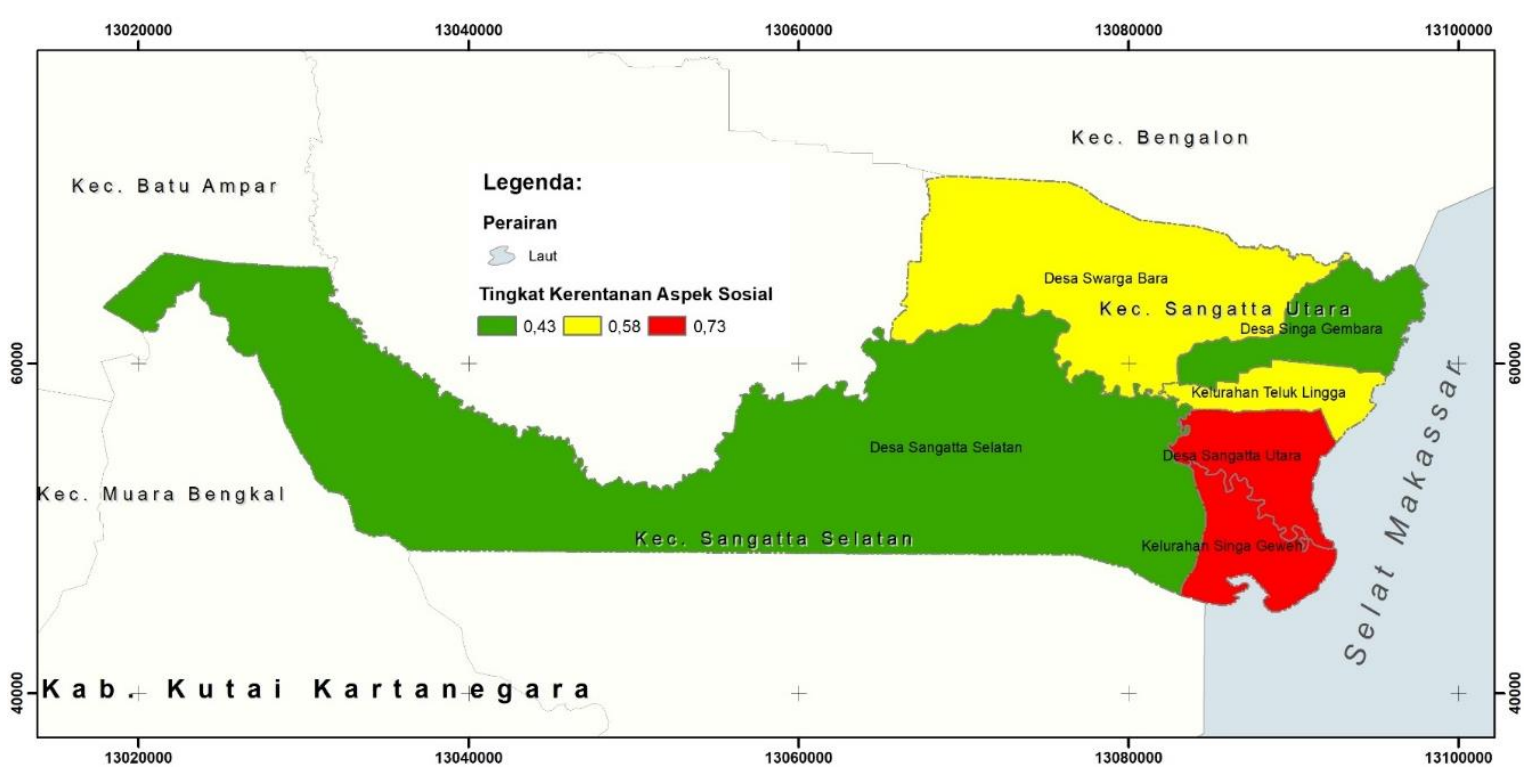

Gambar 5. Peta hasil overlay kerentanan kategori sosial. 
3.3.3. Tingkat kerentanan pada kategori ekonomi. Gambar 6 menunjukkan bahwa setiap kelurahan di wilayah studi memiliki karakteristik yang sama di seluruh faktor ekonomi. Hal ini menunjukkan bahwa pada aspek ekonomi tidak terjadi heterogenitas tingkat kerentanan kebakaran sehingga seluruh faktor dianggap sama. Dengan demikian pembobotan pada analisis weighted sum overlay menghasilkan nilai yang seragam juga seperti pada Gambar 6 . seluruh kelurahan/desa pada wilayah perkotaan Kabupaten Kutai Timur memiliki tingkat kerentanan pada aspek ekonomi sebesar 0,22.

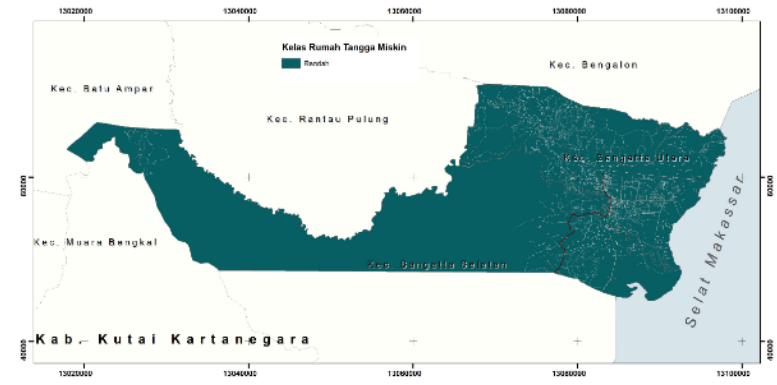

(a)

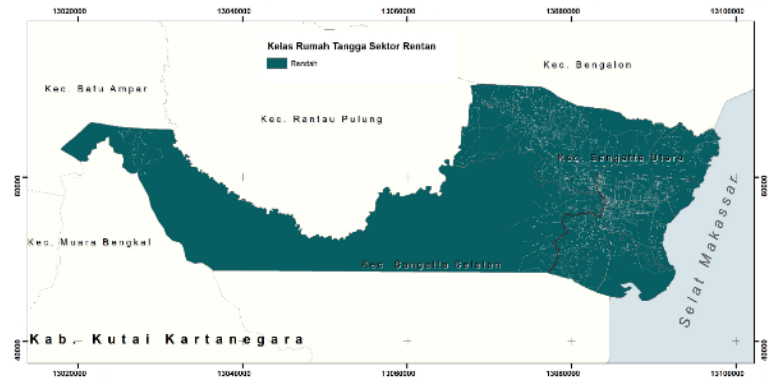

(b)

Gambar 6. Peta tingkat kerentanan ekonomi berdasarkan (a) rumah tangga miskin dan (b) rumah tangga sektor rentan.

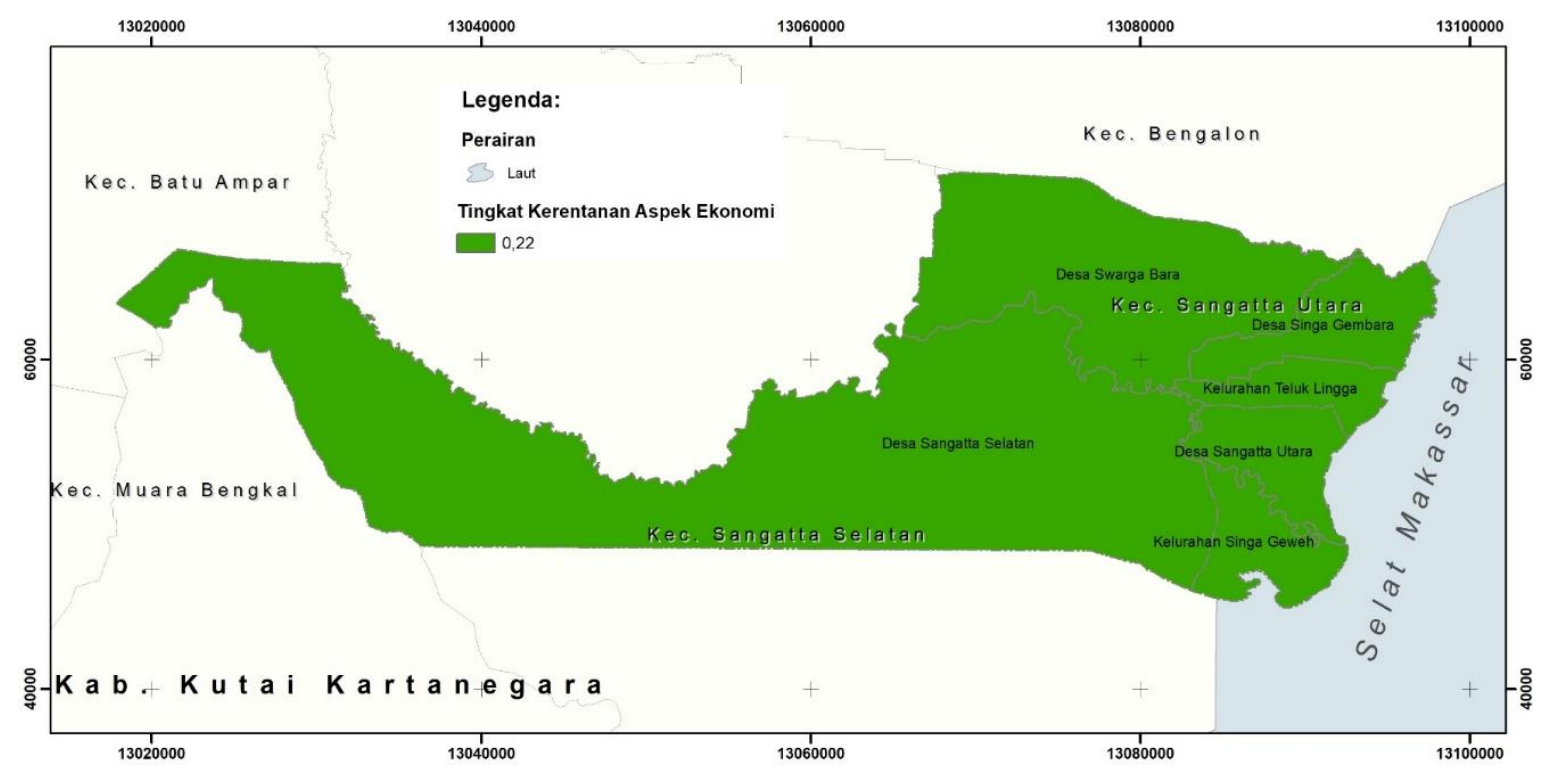

Gambar 7. Peta hasil overlay kerentanan kategori ekonomi.

3.3.4. Tipologi kerentanan kebakaran dari keseluruhan kategori. Setelah didapatkan tingkat kerentanan dengan menggunakan metode weighted sum overlay pada setiap faktor dalam kategori yang sama, kemudian dilakukan analisis weighted sum kembali setiap kategori yaitu kerentanan fisik, kerentanan sosial, dan kerentanan ekonomi. Proses weighted sum overlay antar kategori ini akan menghasilkan tipologi akhir. Pada prosesnya, peta per kategori ditumpang-susunkan dengan diberikan bobot dari tingkat kepentingannya berdasarkan 
analisis AHP seperti pada Gambar 8. Nilai kerentanan akhir pada setiap kategori dari analisis sebelumnya untuk setiap kelurahan/desa dapat disajikan pada Tabel 10.

Tabel 10. Nilai kerentanan tiap kategori di setiap kelurahan/desa.

\begin{tabular}{llccc}
\hline \multirow{2}{*}{ Kelurahan/Desa } & \multicolumn{3}{c}{ Nilai Kerentanan } & \multirow{2}{*}{ Nilai Akhir } \\
\cline { 2 - 4 } & Fisik & Sosial & Ekonomi & \\
\hline Desa Sangatta Selatan & 0,50 & 0,14 & 0,05 & 0,69 \\
Desa Sangatta Utara & 0,50 & 0,24 & 0,05 & 0,78 \\
Desa Singa Gembara & 0,50 & 0,14 & 0,05 & 0,69 \\
Desa Swarga Bara & 0,42 & 0,19 & 0,05 & 0,66 \\
Kelurahan Singa Geweh & 0,50 & 0,24 & 0,05 & 0,78 \\
Kelurahan Teluk Lingga & 0,50 & 0,19 & 0,05 & 0,73 \\
\hline
\end{tabular}

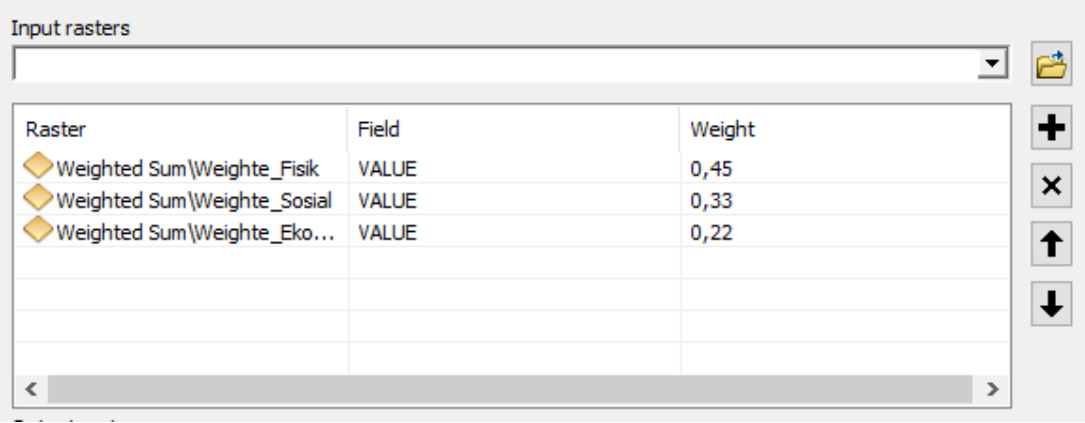

Gambar 8. Proses weighted sum pada tiap aspek kerentanan kebakaran.

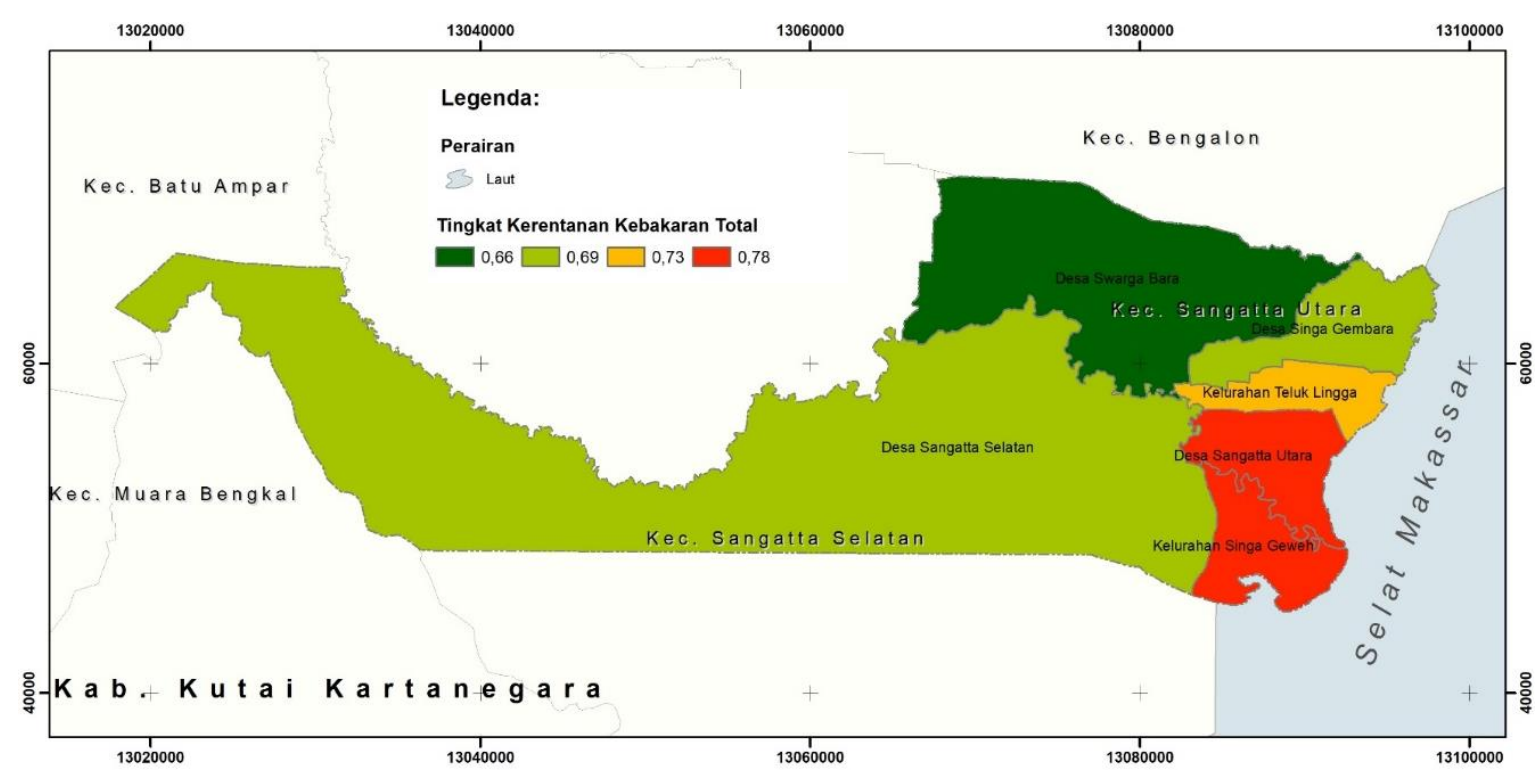

Gambar 9. Peta hasil overlay pembobotan seluruh kategori. 
Setelah mendapatkan nilai total kerentanan, Gambar 9 merupakan hasil peta pembobotan total seluruh kategori kerentanan kebakaran di wilayah perkotaan Kabupaten Kutai Timur. Hasil ini menunjukkan bahwa di setiap kelurahan/desa memiliki nilai akhir yang tidak berbeda jauh. Hal ini dikarenakan nilai aspek sosial saja yang cenderung variatif dan membedakan.

Selanjutnya peta hasil overlay pembobotan seluruh kategori tersebut dibagi ke dalam 3 kelas, yaitu rendah, sedang dan tinggi. Adapun pembagian kelas menggunakan metode equal interval yang terdapat dalam tools classify. Setelah mendapatkan jarak kelas dengan tools classify, maka didapatkan peta hasil klasifikasi. Gambar 10 menunjukkan peta yang telah diklasifikasi.

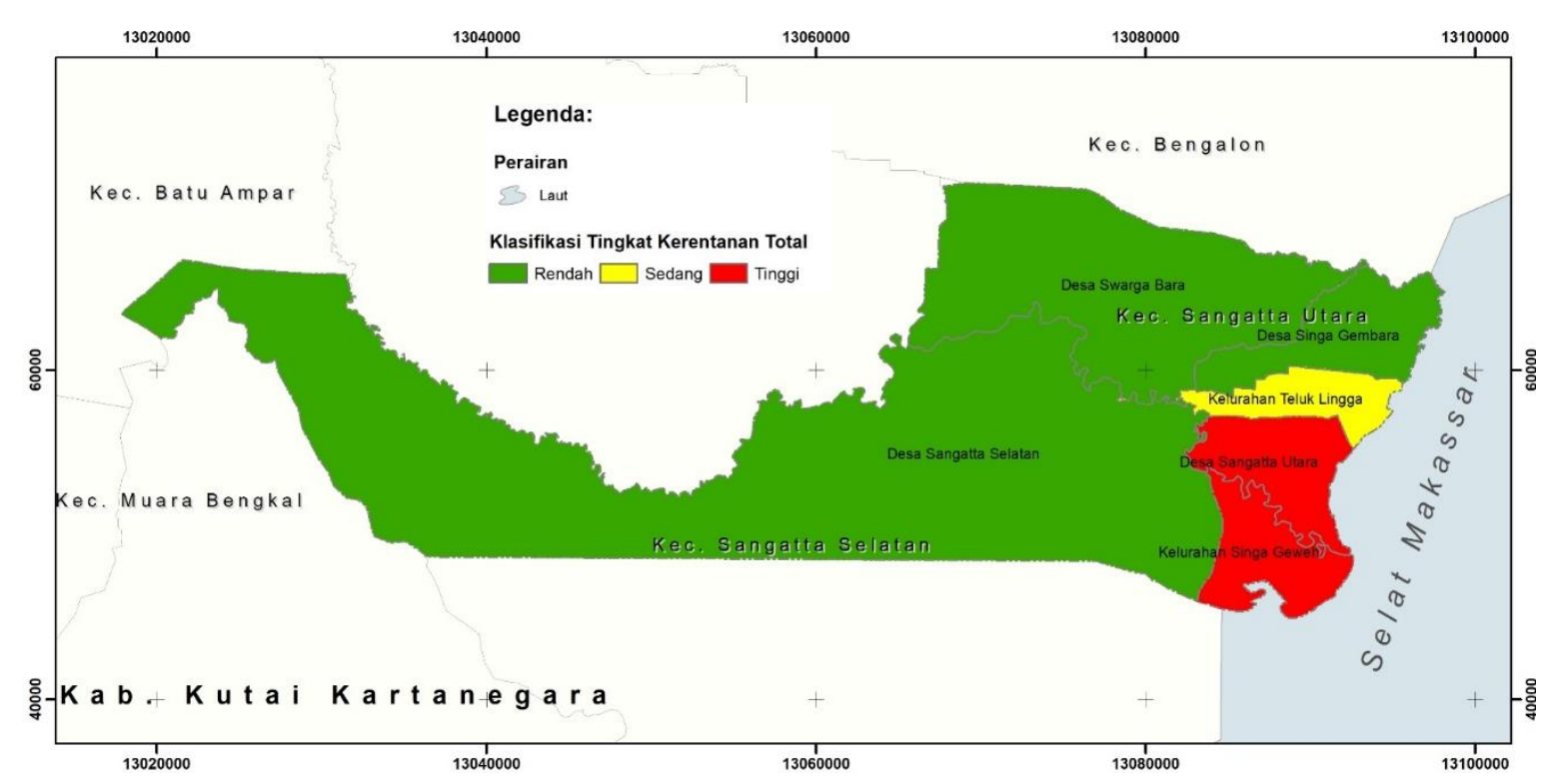

Gambar 10. Peta tipologi kerentanan kebakaran di wilayah perkotaan Kabupaten Kutai Timur.

Dari peta di atas dapat diketahui bahwa Desa Swarga Bara, Desa Singa Gembara, dan Desa Sangatta Selatan termasuk dalam klasifikasi kerentanan rendah. Hal ini dikarenakan pada ketiga desa memiliki tingkat kerentanan sosial sebesar 0,14 hingga 0,19, tingkat kerentanan fisik sebesar 0,42 hingga 0,50, dan tingkat kerentanan ekonomi sebesar 0,05. Kelurahan Teluk Lingga termasuk dalam klasifikasi kerentanan sedang, dimana tingkat kerentanan fisik pada kelurahan ini adalah sebesar 0,50, tingkat kerentanan sosial sebesar 0,19, dan tingkat kerentanan ekonomi sebesar 0,05. Adapun variabel yang paling berpengaruh diantaranya adalah variabel kondisi bangunan dengan bobot 0,51 , ketersediaan hidran dengan bobot 0,36, dan variabel kepadatan penduduk dengan bobot 0,30 .

Desa Sangatta Sangatta Utara dan Kelurahan Singa Geweh termasuk dalam klasifikasi kerentanan dengan kelas tinggi dikarenakan Desa Sangatta Utara dan Kelurahan Singa Geweh memiliki tingkat kerentanan fisik dan kerentanan sosial tertinggi dari kelurahan/desa lainnya yaitu secara berurut adalah 0,50 dan 0,24, serta tingkat kerentanan ekonomi sebesar 0,05. Adapun variabel yang paling berpengaruh diantaranya adalah variabel kondisi bangunan 
dengan bobot 0,51, kepadatan penduduk dengan bobot 0,45 , dan ketersediaan hidran dengan bobot 0,36 . Secara umum, kelurahan/desa yang memiliki tingkat kerentanan tinggi memiliki kepadatan penduduk yang lebih banyak serta kondisi bangunan yang mayoritas adalah bangunan non permanen.

Temuan penelitian ini menunjukkan bahwa kerentanan kebakaran di wilayah perkotaan Kabupaten Kutai Timur masih identik di setiap kelurahan/desa meskipun dapat diklasifikasikan menjadi 3 (tiga) jenis. Hal ini dikarenakan karakteristik data di setiap kelurahan masih identik dan homogen. Pada kelas data, kategori sosial terutama faktor kepadatan penduduk dan kategori fisik pada faktor kepadatan bangunan menjadi faktor kunci dalam heterogenitas tingkat kerentanan. Dengan demikian, pemerintah daerah dan masyarakat perlu menjadikan 2 faktor tersebut sebagai dasar dalam manajemen risiko kebakaran di wilayah perkotaan Kabupaten Kutai Timur.

\section{Kesimpulan}

Penelitian ini menggunakan data sekunder dan menggunakan beberapa teknik analisis, salah satunya adalah analisis AHP untuk pembobotan faktor prioritas kerentanan kebakaran di wilayah perkotaan Kabupaten Kutai Timur. Hasil analisis menunjukkan bahwa kategori fisik dinilai memiliki tingkat kepentingan yang tinggi dibandingkan dengan kategori sosial dan ekonomi. Selain itu, analisis penelitian juga didapatkan bahwa pada wilayah perkotaan Kabupaten Kutai Timur, tepatnya pada Desa Swarga Bara, Desa Singa Gembara, dan Desa Sangatta Selatan memiliki tingkat kerentanan rendah dengan rentang skor antara 0,66 hingga 0,69, Kelurahan Teluk Lingga memiliki kerentanan sedang dengan skor 0,73, serta Kelurahan Singa Geweh dan Desa Sangatta Utara memiliki tingkat kerentanan tinggi dengan 0,78.

\section{Referensi}

[1] Ratcliffe J, Chainey S. GIS And Crime Mapping. Chichester: John Wiley and Sons; 2005.

[2] Masoumi Z, Genderen J van L, Maleki J. Fire Risk Assessment in Dense Urban Areas Using Information Fusion Techniques. ISPRS Int J Geo-Information 2019;8. https://doi.org/10.3390/ijgi8120579.

[3] Twigg J, Christie N, Haworth J, Osuteye E, Skarlatidou A. Improved Methods for Fire Risk Assessment in Low-Income and Informal Settlements. Int J Environ Res Public Health 2017;14. https://doi.org/10.3390/ijerph14020139.

[4] Noor D. Pengantar Mitigasi Bencana Geologi. Yogyakarta: DeePublish; 2014.

[5] Abdalla R, Esmail M. WebGIS for Disaster Management and Emergency Response. Cham: Springer Nature Switzerland AG; 2019. https://doi.org/10.1007/978-3-030-03828-1.

[6] Somantri L. Pemanfaatan Citra Quickbird Dan Sistem Informasi Geografis Untuk Zonasi Kerentanan Kebakaran Permukiman Kasus di Kota Bandung Bagian Barat. J Geogr Gea 2011;11:86-101. https://doi.org/10.17509/gea.v11i1.1656.

[7] Anwar LY. Kerentanan Kebakaran Permukiman Padat di Kelurahan Sidodamai Kecamatan Samarinda Ilir Kota Samarinda. J Azimut 2019;2:121-32.

[8] Granda S, Ferreira TM. Assessing Vulnerability and Fire Risk in Old Urban Areas: Application to the Historical Centre of Guimarães. Fire Technol 2019;55:105-27. 
https://doi.org/10.1007/s10694-018-0778-z.

[9] Permana AY, Susanti I, Wijaya K. Kerentanan Bahaya Kebakaran di Kawasan Kampung Kota. Kasus: Kawasan Balubur Tamansari Kota Bandung. J Arsit Zo 2019;2:32-45. https://doi.org/10.17509/jaz.v2i1.15208.

[10] Moran A. Project Risk Management. Agil. Risk Manag., Cham: Springer; 2014, p. 17-32. https://doi.org/10.1007/978-3-319-05008-9_2.

[11] Knezevcic D, Krsmanovic M, Zivkovic N, Dukanac M. Assessment of the Stakeholders' Importance Using AHP Method - Modeling and Application. Manag J Sustain Bus Manag Solut Emerg Econ 2015;20:13-24. https://doi.org/10.7595/management.fon.2015.0008.

[12] Shi L, Zhang R, Xie Q, Fu L. Improving Analytic Hierarchy Process Applied to Fire Risk Analysis of Public Building. Chinese Sci Bull 2009;54:1442-50. https://doi.org/10.1007/s11434-009-0056-z.

[13] Wang Y, Hou L, Li M, Zheng R. A Novel Fire Risk Assessment Approach for Large-Scale Commercial and High-Rise Buildings Based on Fuzzy Analytic Hierarchy Process (FAHP) and Coupling Revision. Int J Environ Res Public Health 2021;18:7187. https://doi.org/10.3390/ijerph18137187.

[14] Saaty TL. Deriving the AHP 1-9 Scale form First Principles. 6th ISAHP 2001, Berne: ISAHP; 2001, p. 397-402. https://doi.org/10.13033/isahp.y2001.030.

[15] Saaty TL. Decision making - the Analytic Hierarchy and Network Processes (AHP/ANP). J Syst Sci Syst Eng 2004;13:1-35. https://doi.org/10.1007/s11518-006-0151-5.

[16] Peraturan Kepala Badan Nasional Penanggulangan Bencana Nomor 2 Tahun 2012 Tentang Pedoman Umum Penanggulangan Risiko Bencana.

[17] Sulasmi. Analisis Kerentanan Kebakaran Permukiman Menggunakan Sistem Informasi Geografis di Kecamatan Depok Kabupaten Sleman. Universitas Negeri Yogyakarta, 2014. 